\title{
CHARACTERISATION OF CRYPTIC PLASMIDS IN CLINICAL ISOLATES OF BACTEROIDES FRAGILIS
}

\author{
H. A. Beul, Ch. von Eichel-Streiber, M. Schreiner, F. P. Schwindling, D. \\ Weinblum, E. J. ZÖllner AND M. Dierich*
}

\section{Physiologisch-Chemisches Institut and ${ }^{*}$ Institut für Medizinische Mikrobiologie der Universität, 6500 Mainz, West Germany}

\begin{abstract}
SUMmARY. A screening method for plasmids in the fragilis group of Bacteroides spp. was developed, taking account of the lysozyme resistance of these species; 26 strains, 24 of them $B$. fragilis, were investigated by this method. Eleven strains contained plasmids and up to three different plasmids were found in individual strains. The plasmids belonged to five different size classes of mol. wt $\left(10^{6}\right) 2 \cdot 8,3 \cdot 5$, $3 \cdot 6,4 \cdot 2$ and 19. Plasmids of equal size showed homology; no homology was found between plasmids of different sizes. Plasmids of equal size showed identical restriction patterns with 17 restriction endonucleases. Restriction maps were constructed for the five classes of plasmid.
\end{abstract}

\section{INTRODUCTION}

The Bacteroides fragilis group represents a significant part of the human intestinal microflora and these organisms are also of clinical importance as a cause of purulent infections in man (for reviews see Dowell and Lombard, 1981; Werner, 1981). However, it is not known whether or not the bacterial strains that cause such infections differ from symbiotic intestinal strains by the possession of specific pathogenicity factors.

Such factors are required for other clinically-important bacterial species and are frequently encoded on plasmids (for reviews see Cabello and Timmis, 1979; Elwell and Shipley, 1980). Functions connected with pathogenicity have not yet been detected on bacteroides plasmids. The only functions of clinical relevance identified in a few cases on plasmids are antibiotic resistances (Mancini and Behme, 1977; Guiney and Davis, 1978; Privitera et al., 1979 and 1981; Tally et al., 1979, 1981 and 1982; Welch et al., 1979; Palchaudhuri and Bawdon, 1980; Magot et al., 1981; Malamy and Tally, 1981; Rashtchian and Booth, 1981; Rotimi, et al. 1981).

A prerequisite for the identification of plasmid-coded pathogenicity factors is the determination of the plasmid distribution pattern in the bacterial species. Therefore, several publications concerning the plasmid content of different Bacteroides spp. have appeared. Stiffler et al. (1974) first reported the occurence of plasmids in B. fragilis. More recently, comprehensive surveys have been performed on the plasmid content of different species of Bacteroides by Mays and Johnson (1979), Wallace et al. (1981) and 
Callihan et al. (1983). In these investigations, mostly small cryptic plasmids have been found in $c .40 \%$ of all strains either from intestinal or from clinical origin.

We have extended these surveys to compare American with European Bacteroides strains. Because $B$. fragilis is found more frequently in clinical isolates than other Bacteroides spp. (Dowell and Lombard, 1981; Werner, 1981), we screened 24 strains of this species for their plasmid content. Plasmids obtained by the screening procedure were characterised by restriction mapping and tested for homology by hybridisation.

\section{MATERIALS AND METHODS}

Bacterial strains. All strains of Bacteroides were clinical isolates from suppurative infections in man. They were isolated at the Institutes of Medical Microbiology of the Universities of Bonn (strains 19610, 23262, 23553, 24102, 25400, 25407, 25448, 25989, 26023, 26458, 26732, 1034, $1249,1430,1492,1560,2016,2028,2769$ and 2869), Marburg (strains 1396, 16553, and 16547) and Mainz (strains 2457, 3292 and 4430). The isolates were identified by standard biochemical methods (Holdeman and Moore, 1974). Stock cultures were maintained on Wilkins-Chalgren Agar (Oxoid) at $4^{\circ} \mathrm{C}$ and passaged twice a month through Thioglycollate Medium U.S.P. (Oxoid). Bacteria were cultivated in defined medium (Varel et al., 1974) without using an anaerobic jar. Agar plates were incubated anaerobically in anaerobic jars (Oxoid). B. fragilis TM4003, which carries the clindamycin-resistance plasmid pBFTM10, was obtained from Dr F. P. Tally, Boston, MA. Escherichia coli reference strains PRC304 and PRC194, which carry the resistance plasmids RSF1030 and R1 respectively, the colicin-producing strains PRC-595 (ColE3), PRC628(ColA-CA31) and the colicin-sensitive strains PRC072 and JA300 were obtained from Dr E. Lederberg (Plasmid Reference Center, Stanford University, Stanford, CA). E. coli strains were grown in Standard Nutrient Broth (Merck) and stored on Standard-I Nutrient Agar (Merck) at $4^{\circ} \mathrm{C}$.

Buffers and solutions were prepared as follows: TB buffer: $90 \mathrm{~mm}$ Tris- $\mathrm{HCl}, p \mathrm{H} 8 \cdot 3,2.5 \mathrm{~mm}$ EDTA, $90 \mathrm{~mm}$ boric acid. TE buffer: $50 \mathrm{~mm}$ Tris- $\mathrm{HCl}, p \mathrm{H} 8,1 \mathrm{~mm}$ EDTA. SDS solution: $50 \mathrm{~mm}$ Tris- $\mathrm{HCl}, p \mathrm{H} 8 \cdot 0$, sodium dodecyl sulphate (SDS) $15 \%$. Alkaline SDS solution: SDS $3 \%$ adjusted to $p \mathrm{H} 12.6$ with $2 \mathrm{M} \mathrm{NaOH}$. Stop mixture: 50mm EDTA, $5 \mathrm{~mm}$ Tris- $\mathrm{HCl}, p \mathrm{H} \mathrm{8.0.} \mathrm{Restriction}$ buffer: $10 \mathrm{~mm}$ Tris, $p \mathrm{H} 7 \cdot 7,6 \mathrm{mM} \mathrm{MgCl}, 0 \cdot 2 \mathrm{~mm}$ EDTA, $\beta$-mercaptoethanol $0 \cdot 1 \%$, bovine serum albumin $0.1 \mu \mathrm{g} / \mathrm{ml}$, in $0.85 \% \mathrm{NaCl}$ according to the specifications of the suppliers.

Plasmid screening procedure. Bacteria from 1-ml overnight cultures were harvested by centrifugation and suspended in $100 \mu \mathrm{l}$ of TE buffer. Then $100 \mu \mathrm{l}$ of alkaline SDS solution was added. The mixture was incubated at $85^{\circ} \mathrm{C}$ for $15 \mathrm{~min}$, cooled to $20^{\circ} \mathrm{C}$ and kept at room

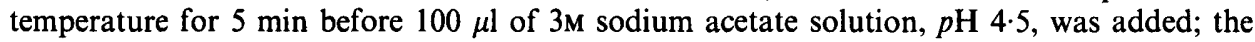
preparation was kept on ice for another $5 \mathrm{~min}$. Cell debris and chromosomal DNA were then removed by centrifugation at $8000 \mathrm{~g}$ for $5 \mathrm{~min}$ at room temperature. The supernate was mixed with an equal volume of phenol:chloroform $(1: 1, v: v)$. DNA in the aqueous phase was precipitated with two volumes of ethanol, then dissolved in $20 \mu \mathrm{l}$ of TE buffer and subjected to electrophoresis.

Large scale plasmid preparation. Bacteria from $1.5 \mathrm{~L}$ of culture medium were harvested by centrifugation and washed with TE buffer. The $c .8 \mathrm{~g}$ wet weight of bacteria thus obtained was suspended in $40 \mathrm{ml}$ of sucrose $25 \%$ in $50 \mathrm{~mm}$ Tris solution, $p H 8 ; 40 \mathrm{ml}$ of $250 \mathrm{~mm}$ EDTA solution was added and the suspension was stirred for $10 \mathrm{~min}$. Then $50 \mathrm{ml}$ of $15 \%$ SDS solution was added, the mixture heated to $70^{\circ} \mathrm{C}$ and gently shaken at this temperature for $15 \mathrm{~min}$, after which $50 \mathrm{ml}$ of $5 \mathrm{M} \mathrm{NaCl}$ solution were added and the mixture was kept on ice for $30 \mathrm{~min}$. Precipitate was removed by centrifugation at $10000 \mathrm{~g}$ for $10 \mathrm{~min}$ at $4^{\circ} \mathrm{C}$. RNAase was added to the supernate to give a final concentration of $10 \mu \mathrm{g} / \mathrm{ml}$ and the mixture was incubated at $37^{\circ} \mathrm{C}$ for $1.5 \mathrm{~h}$. DNA was precipitated from the solution by adding polyethylene glycol (56 ml of PEG $600040 \%$ in TE buffer) and holding the mixture for $30 \mathrm{~min}$ on ice. The precipitate was collected by centrifugation at $10000 \mathrm{~g}$ for $10 \mathrm{~min}$ at $4^{\circ} \mathrm{C}$ and was redissolved in $20 \mathrm{ml}$ of $50 \mathrm{~mm}$ Tris, $p \mathrm{H} 8$. The solution was heated to $70^{\circ} \mathrm{C}$ and $20 \mathrm{ml}$ of prewarmed alkaline SDS solution was added. After $10 \mathrm{~min}$, the mixture was cooled on ice and $20 \mathrm{ml}$ of $3 \mathrm{M}$ sodium acetate $(p \mathrm{H} 4.8)$ was added. After $30 \mathrm{~min}$, the precipitate was removed by centrifugation (as above) and the supernate was treated with $60 \mathrm{ml}$ of 
phenol:chloroform $(1: 1, \mathrm{v}: \mathrm{v})$. From the aqueous phase, the DNA was precipitated with two volumes of ethanol and redissolved in $300 \mu \mathrm{l}$ of TE buffer. Final purification was achieved by RbTCA centrifugation as described by Zöllner et al. (1983).

Agarose-gel electrophoresis. DNA was subjected to horizontal slab-gel electrophoresis in $0.7 \%$ agarose at room temperature for $4 \mathrm{~h}(150 \mathrm{~V}$, constant voltage; c. $40 \mathrm{~mA})$. After electrophoresis, gels were stained with ethidium bromide $(0.5 \mu \mathrm{g} / \mathrm{ml}$ in TB buffer) for $30 \mathrm{~min}$, examined with a Chromato-vue transilluminator (Ultra-violet Products, USA) and photographed through a yellow filter on Polaroid Land Film 667.

Isolation of plasmid DNA from agarose gels. Plasmids from bacterial strains that contained two or more plasmids were separated by electrophoresis in low-gelling agarose gels (Sigma). Bands containing the plasmids were cut from the gels and DNA was extracted according to the methods of Maniatis et al. (1982).

Radioactive labelling of plasmid DNA. Radioactively labelled plasmid DNA was prepared by nick translation according to the methods of Rigby et al. (1977). DNAase I, E. coli polymerase I and deoxynucleosidetriphosphates were obtained from Boehringer Mannheim; ${ }^{32} \mathrm{P}$ dTTP (800 $\mathrm{Ci} / \mathrm{mm}$ ) was obtained from Amersham.

Hybridisation of plasmid DNA. Transfer of DNA from agarose gels to nitrocellulose filters (BRL) and hybridisation with radioactive plasmid DNA was done as described by Maniatis $e t$ al. (1982). Autoradiography was done overnight on Kodak X-Omat AR film at $-70^{\circ} \mathrm{C}$.

Restriction-endonuclease digestion. Plasmid digestion was performed as described by Maniatis et al. (1982). Restriction enzymes were obtained from BRL (USA), Miles (USA) and Boehringer (Germany) and used as recommended by the suppliers. Approximately $0 \cdot 1-0 \cdot 2 \mu \mathrm{g}$ of DNA in $14 \mu \mathrm{l}$ of restriction buffer were mixed with 5 units of restriction endonuclease and incubated at $37^{\circ} \mathrm{C}$ for $60 \mathrm{~min}$. Reactions were stopped by adding $6 \mu \mathrm{l}$ of stop mixture and $10 \mu \mathrm{l}$ of bromophenol blue solution; then the solution was heated to $65^{\circ} \mathrm{C}$ for $5 \mathrm{~min}$. DNA fragments were separated by gel electrophoresis in $0.9 \%$ agarose at $5 \mathrm{~V} / \mathrm{cm}$. Size analysis of restriction fragments was performed by a computer programme of Schaffer and Sedereff (1981) with a phage lambda DNA Hind III digest as internal standard. For partial digestions, the reactions were stopped after 1, 2, 5, 10,20,60 or $120 \mathrm{~min}$. For simultaneous digestions with two restriction endonucleases, the enzyme requiring the lower salt concentration was added first. After the initial incubation period, the salt concentration was adjusted by adding the appropriate amount of $0.7 \mathrm{M} \mathrm{NaCl}$ solution. Then the second enzyme was added and the sample reincubated.

Electronmicroscopy. A purified preparation of pZW1709 DNA, which had been stored at $4^{\circ} \mathrm{C}$ to enrich the open circular form, was used in electronmicroscopy studies for homoduplex analysis. DNA was denatured by heating at $95^{\circ} \mathrm{C}$ for $1.5 \mathrm{~min}$, allowed to reanneal for 1,5 or 30 min and then was spread according to the formamide technique of Sharp et al. (1973). Plasmids RSF1030 and R1 served as references.

Bacteriocin production and antibiotic resistance. Bacteriocin production was tested according to the method of Riley and Mee (1981). Antibiotic resistance was determined by the agar-dilution method (Nasu et al., 1981) on Wilkins-Chalgren Agar. Penicillin, tetracycline and erythromycin (Merck, BRD), clindamycin (Hoechst, BRD), and ampicillin, kanamycin, streptomycin, chloramphenicol and rifampicin (Serva, BRD) were tested at doubling concentrations from 0.025 to $100 \mathrm{mg} / \mathrm{L}$.

Curing. Bacteria were cultivated in Thioglycollate Medium (Oxoid) in the presence of ethidium bromide $15 \mu \mathrm{g} / \mathrm{ml}$. After dilution they were spread on Wilkins-Chalgren Agar. Single colonies were picked from the plates, reincubated in $1.5 \mathrm{ml}$ of thioglycollate medium and analysed for their plasmid content as described above.

\section{RESULTS}

\section{Plasmid screening and isolation procedures}

Control experiments with $E$. coli standard plasmids confirmed that plasmids up to a mol. wt of at least $60 \times 10^{6}$ could be isolated by treatment of cells with alkaline SDS 
TABLE I

Plasmid-containing Bacteroides strains

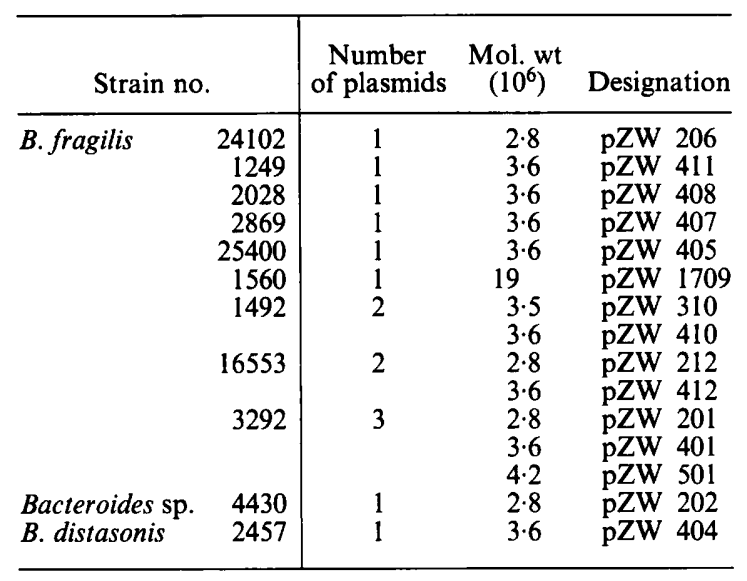

solution at $85^{\circ} \mathrm{C}$ for $15 \mathrm{~min}$. This method was used for plasmid screening in Bacteroides strains.

\section{Plasmid content of B. fragilis strains}

Nine of the 24 strains of $B$. fragilis carried one to three plasmids, which fell into five size classes (table I). Two strains of species other than $B$. fragilis also harboured plasmids of sizes already found in the $B$. fragilis strains.

\section{Endonuclease digestion maps}

Eight plasmids that occurred singly were digested with 17 restriction endonucleases (table II). The two plasmids from strain 16553 and the three from strain 3292 were separately isolated from agarose gels and digested with the same enzymes. Plasmids of identical size gave identical restriction patterns with all the enzymes tested.

Because of the small difference in their sizes, the two plasmids from strain 1492 could not be separately isolated from the gel and were jointly digested with the 17 enzymes. The restriction patterns always gave the fragments expected for the plasmids of mol. wt $3.6 \times 10^{6}$ as well as other fragments. The fragments of the plasmid of mol. wt $3.5 \times 10^{6}$ were obtained by subtraction.

The different fragments of the five size classes are listed in table II. Restriction maps were constructed from partial digestions or from double digestions with appropriate enzymes. The maps are depicted in fig. 1.

\section{Screening homology of plasmids}

Southern blots containing the plasmids of the eleven plasmid-carrying strains were prepared. Plasmids pZW206, pZW408 and pZW502, mol. wt $\left(10^{6}\right) 2 \cdot 8,3 \cdot 6$ and $4 \cdot 2$ respectively, were labelled by nick translation and hybridised against the blots. Only 
TABLE II

List of fragments produced by endonuclease digestion of plasmids from B. fragilis

\begin{tabular}{|c|c|c|c|c|c|}
\hline \multirow[t]{2}{*}{ Enzyme } & \multicolumn{5}{|c|}{$\begin{array}{l}\text { Length of fragments (in base pairs) from } \\
\text { plasmids of mol. wt }\left(10^{6}\right)\end{array}$} \\
\hline & $2 \cdot 8$ & 3.5 & 3.6 & $4 \cdot 2$ & 19 \\
\hline $\begin{array}{l}\text { AluI } \\
\text { AvaI }\end{array}$ & $\stackrel{*}{-}$ & $\stackrel{*}{*}{ }_{5300}$ & $\stackrel{*}{-}$ & $\stackrel{*}{-}$ & $\begin{array}{c}* \\
28900 \\
1100\end{array}$ \\
\hline $\begin{array}{l}\text { AvaII } \\
\text { BamHI } \\
\text { BgII }\end{array}$ & E & - & $\begin{array}{c}5500 \\
- \\
-\end{array}$ & E & $\begin{array}{l}30000 \\
30000 \\
23000\end{array}$ \\
\hline$D d e \mathrm{I}$ & $\begin{array}{r}1720 \\
720 \\
660 \\
580 \\
560\end{array}$ & $\begin{array}{r}2400 \\
1150 \\
950 \\
600 \\
200\end{array}$ & $\begin{array}{l}3000 \\
2500\end{array}$ & $*$ & 7000 \\
\hline EcoRI & - & - & - & $\begin{array}{l}3600 \\
2800\end{array}$ & $\begin{array}{r}25400 \\
4600\end{array}$ \\
\hline HaeIII & - & - & $\begin{array}{r}4650 \\
850\end{array}$ & - & - \\
\hline HindIII & - & $\begin{array}{l}3200 \\
2100\end{array}$ & - & 6400 & $\begin{array}{r}27200 \\
2800\end{array}$ \\
\hline $\begin{array}{l}\text { HpaII } \\
\text { PstI }\end{array}$ & $\stackrel{*}{-}$ & 5300 & $\begin{array}{c}* \\
5500\end{array}$ & $\stackrel{*}{-}$ & + \\
\hline $\begin{array}{l}\text { PvulI } \\
\text { SacI }\end{array}$ & $\overline{4200}$ & $\begin{array}{l}\overline{ } \overline{3900} \\
1100\end{array}$ & $\frac{-}{5500}$ & $\bar{z}$ & $\overline{7}^{\dagger}+$ \\
\hline $\begin{array}{l}\text { SalI } \\
\text { SmaI } \\
\text { SphI } \\
\text { XhoI }\end{array}$ & E & $\begin{array}{c}\frac{300}{5300} \\
- \\
-\end{array}$ & $\begin{array}{l}- \\
z\end{array}$ & $\bar{z}$ & $\begin{array}{l}z^{+} \\
{ }_{-}^{+}\end{array}$ \\
\hline
\end{tabular}

* More than 10 fragments, size not determined.

$\dagger$ Activity of enzyme was tested with pBR322 DNA.

hybridisation with plasmids of the same size was observed. The two plasmids of strain 1492 were labelled together and hybridised against a blot. In comparison to the test with pZW408, only one additional band was observed indicating hybridisation of the plasmid of mol. wt $3.5 \times 10^{6}$ with itself. From these results we concluded that all the small plasmids of different sizes belonged to different homology classes.

The large plasmid pZW1709 did not react with the radioactive probes and, therefore, belonged to a separate homology class. Finally, the plasmid pBFTM10 from strain TM4003, which contains a resistance gene for clindamycin, was used as a probe with our plasmids; none showed any hybridisation with pBFTM10.

From these results and from the results of the restriction analysis we assume, as a working hypothesis, that plasmids of the same size are identical.

\section{Homoduplex analysis}

Inverted repeats indicating the occurence of transposon-like structures in a plasmid can be identified by homoduplex analysis. Optimal experimental conditions for the demonstration of homoduplices by electronmicroscopy were determined with the transposon-containing plasmids RSF1030 and R1. With these plasmids, homodup- 

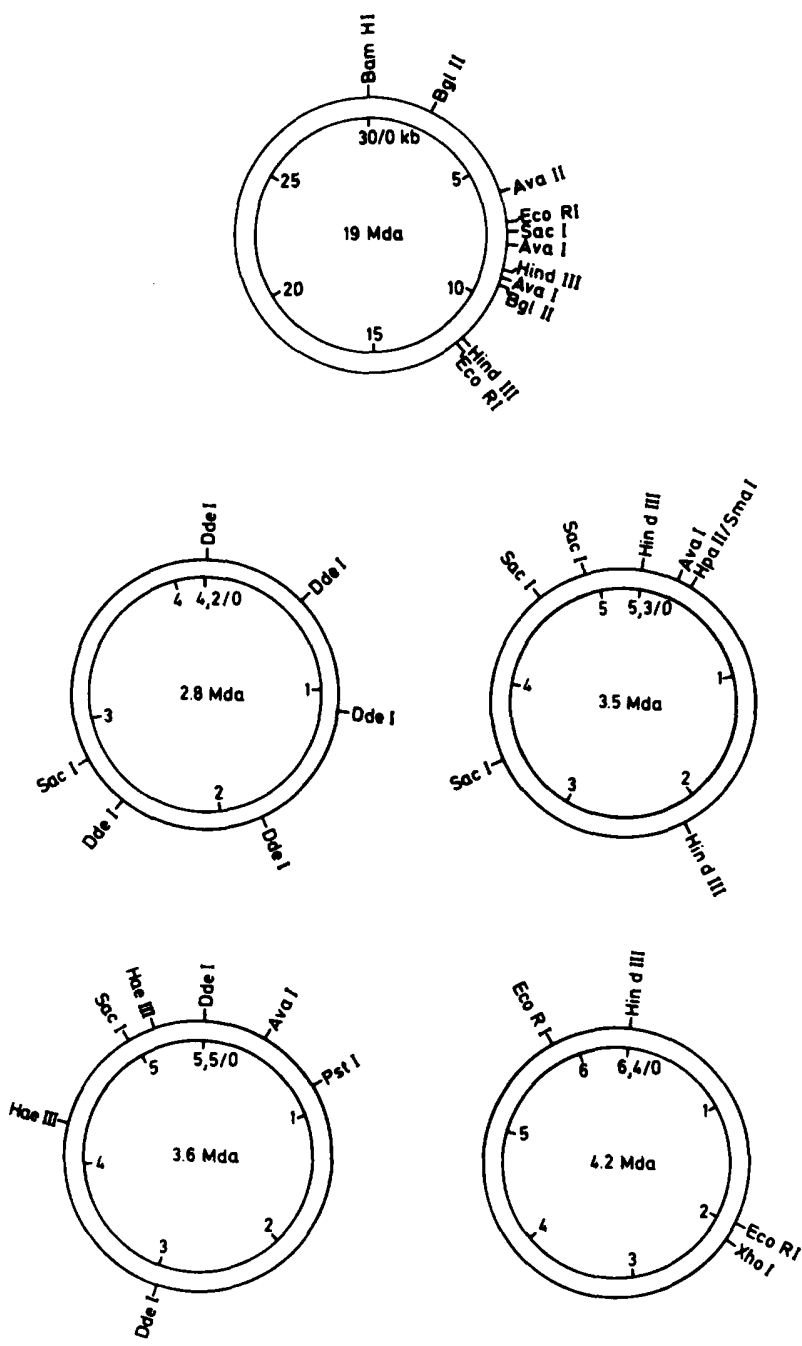

FIG. 1.-Restriction maps of the large and the four small plasmids isolated from the $B$. fragilis strains.

lices could be demonstrated in high yield, but no homoduplex could be shown with pZW 1709. The small plasmids were not included in this analysis, because occurence of transposons in plasmids of such size seemed improbable.

\section{Bacteriocin production and antibiotic resistance}

All plasmid-carrying strains and the plasmid-free strains 25989, 23553, 25407 and 16547 were tested for bacteriocin production against each other. No inhibition of growth was observed. The assay procedure was tested with colicin-producing $E$. coli strains PRC595(ColE3) and PRC628(ColA-CA31) against the colicin-sensitive strains PRC072 and JA300 and the expected inhibition was observed. Colicin ColE3 even 
showed weak inhibition of Bacteroides strain 23553. We conclude, therefore, that our plasmids do not code for bacteriocin production.

The same 15 Bacteroides strains were tested for resistance to nine antibiotics (see Materials and methods). No correlation between plasmid content and antibiotic resistance was observed.

\section{Stability of plasmid content}

Because no selection marker for any of the plasmids is known yet, curing experiments were difficult to perform. We cultivated the strains 2028, 2869 and 3292 for $48 \mathrm{~h}$ in the presence of subinhibitory concentrations of ethidium bromide as proposed by Rotimi and Duerden (1982) and analysed approximately 200 single colonies from each strain for their plasmid content. No loss of plasmids was observed. Additionally, strain 2896 was subcultured 20 times successively in the presence of ethidium bromide; after each subcultivation 20 colonies were analysed, but no loss of plasmids was observed. Furthermore, the plasmid-carrying strains were passaged approximately twice a month for a period of 2 years without loss of plasmids.

\section{Discussion}

B. fragilis cells normally are resistant to digestion by lysozyme (Werner, 1981). Even lysis by neutral SDS at elevated temperatures (Hansen and Olsen, 1978) or by alkaline SDS at lower temperature (Birnboim and Doly, 1979) gives unsatisfactory results. However, hot alkaline SDS treatment (Kado and Liu, 1981) produces an acceptable yield of plasmids; a slight modification of this procedure, namely incubation at $85^{\circ} \mathrm{C}$ for $15 \mathrm{~min}$, additionally leads to a significant loss of RNA. This method proved to be a good compromise between yield and purity.

Of the 24 strains of $B$. fragilis investigated, nine strains $(37 \%)$ contained up to three different plasmids. Mostly small plasmids were found, ranging in size from $2.8 \times 10^{6}$ to $3.6 \times 10^{6} \mathrm{~mol}$. wt. Only one strain contained a larger plasmid of mol. wt $19 \times 10^{6}$. Five size classes of plasmids were found with no apparent homology between different classes. Plasmids belonging to the same class, however, showed sequence homology and gave identical restriction patterns with the 17 endonucleases tested. They were, therefore, tentatively considered to be identical. Two of the plasmids were also found in Bacteroides strains of species other than B. fragilis. The same plasmids were found in strains from different locations in Germany.

These observations resemble the results of recent investigations by Mays and Johnson (1979), Wallace et al. (1981) and Callihan et al. (1983) of clinical and intestinal isolates of $B$. fragilis. These authors found small plasmids belonging to several homology classes in about $40 \%$ of all strains investigated. Occurrence of more than one plasmid in a strain was fairly common and apparently-identical plasmids were observed in different species of Bacteroides. Large plasmids were found less frequently. From the plasmid sizes reported by Wallace et al. (1981) and from the sizes and the restriction patterns reported by Callihan et al. (1983) we conclude that the plasmids isolated by these groups were different from the plasmids found in our investigation. Our plasmids are also nonhomologous to the well characterised bacteroides resistance plasmid pBFTM10. 
Summarising the results of this and of the previous investigations, we have to consider it to be a well established fact that a rather high number of different, nonhomologous and compatible small plasmids exist and that a high proportion of American as well as European $B$. fragilis strains contain such plasmids. The question arises, which biological functions do these plasmids encode? Because the plasmids occur in both intestinal and clinical strains, we agree with Callihan et al. (1983) that the plasmids probably do not code for pathogenicity factors. The only functions identified so far on small bacteroides plasmids are antibiotic resistance (Palchaudhuri and Bowdon, 1980; Rashtchia and Booth, 1981); furthermore, a correlation between one small plasmid and bacteriocin production has been observed (Mays and Johnson, 1979). We found that our plasmids did not code for these functions.

The plasmid content of the Bacteroides strains in this investigation was remarkably stable. While Rotimi and Duerden (1982) reported curing rates of up to $100 \%$ for resistance plasmids in Bacteroides spp, we must conclude from our data that curing rates for three of the small plasmids are $<1 \%$. This may indicated that these plasmids are of biological importance for the corresponding strains.

The conspicious feature of the plasmid pattern of Bacteroides strains is, on one hand, the similarity in size and frequency of occurence, and on the other hand, the nonhomology of the small plasmids. Because of the nonhomology, it is difficult to envisage a similar function for all of them. It is possible that the apparent similarity of the occurence pattern is accidental and that each plasmid may code for a totally different function. The occurence of more than one plasmid in one strain, which is observed rather frequently, suggests the latter to be more probable. The elucidation of the biological role of small plasmids in Bacteroides spp. will certainly help to understand the biology of this clinically important microorganism and will be subject of further investigations.

We thank Drs H. Werner, Bonn, and F. P. Tally, Boston, for supplying bacterial strains. The excellent technical assistance of Mrs A. Rohrbacher is acknowleged. Mrs V. Pondeljak helped to prepare the electronmicrographs. This investigation was supported by a grant from the Deutsche Forschungsgemeinschaft.

\section{REFERENCES}

Birnboim H C, Doly J 1979 A rapid alkaline extraction procedure for screening recombinant plasmid DNA. Nucleic Acid Research 7:1513-1523.

Cabello F, Timmis K N 1979 Plasmids of medical importance. In: Timmis K N, Pühler A (eds) Plasmids of medical, environmental and commercial importance. Elsevier/North-Holland Biomedical Press, Amsterdam, pp 55-69.

Callihan D R, Young F E, Clark V L 1983 Identification of three homology classes of small, cryptic plasmids in intestinal Bacteroides species. Plasmid 9:17-30.

Dowell V R, Lombard G L 1981 Pathogenic members of the genus Bacteroides. In: Starr M P et al. (eds) The Prokaryotes. Springer, Berlin, pp 1425-1449.

Elwell L P, Shipley P L 1980 Plasmid-mediated factors associated with virulence of bacteria to animals. Annual Review of Microbiology 34:465-496.

Guiney D G, Davis C E 1978 Identification of conjugative R plasmid in Bacteroides ochraceus capable of transfer to Escherichia coli. Nature 274:181-182.

Hansen J B, Olsen R H 1978 Isolation of large bacterial plasmids and characterization of the P2 incompatibility group plasmids pMGl and pM65. Journal of Bacteriology 135:227-238.

Holdeman L V, Moore W E C 1974 Bacteroides. In: Buchanan R E, Gibbons N E (eds) Bergey's 
Manual of determinative bacteriology, 8th edn. Williams and Wilkins, Baltimore, MD, pp 385-404.

Kado C I, Liu S T 1981 Rapid procedure for detection and isolation of large and small plasmids. Journal of Bacteriology 145:1365-1373.

Magot M, Fayolle F, Privitera G, Sebald M 1981 Transposon-like structures in the Bacteroides fragilis MLS plasmid plP410. Molecular and General Genetics 181:559-561.

Malamy M H, Tally F P 1981 Mechanisms of drug-resistance transfer in Bacteroides fragilis. Journal of Antimicrobial Chemotherapy 8 Suppl. D: 59-75.

Mancini C, Behme R J 1977 Transfer of multiple antibiotic resistance from Bacteroides fragilis to Escherichia coli. Journal of Infectious Diseases 136:597-600.

Maniatis T, Fritsch E F, Sambrook J 1982 Molecular Cloning. A Laboratory Manual. Cold Spring Harbor Laboratory, Cold Spring Harbor, NY.

Mays T D, Johnson J L 1979 Plasmid DNA homology studies of Bacteroides fragilis and related species. Plasmid 2:299.

Nasu M, Nakatomi M, Saito, A Hara K 1981 Susceptibility of the species of genus Bacteroides recently isolated from clinical specimens to 20 antimicrobial agents. Arzneimittelforschung 31:764-770.

Palchaudhuri S, Bawdon R E 1980 Plasmid mediated clindamycin resistance in Bacteroides fragilis. In: Stuttard C, Rozee K R (eds) Plasmids and transposons: Environmental effects and maintenance mechanisms. Academic Press, New York, pp 129-135.

Privitera G, Botta G, Sebald M 1981 Macrolide, lincosamide, streptogramin and tetracyclin transferable resistance in the Bacteroides fragilis group. Journal of Antimicrobial Chemotherapy 8 Suppl D: 87-94.

Privitera G, Dublanchet A, Sebald M 1979 Transfer of multiple antibiotic resistance between subspecies of Bacteroides fragilis. Journal of Infectious Diseases 139:97-101.

Rashtchian A, Booth S J 1981 Stability in Escherichia coli of an antibiotic resistance plasmid from Bacteroides fragilis. Journal of Bacteriology 146:121-127.

Rigby P W J, Dieckmann M, Rhodes C, Berg P 1977 Labeling deoxyribonucleic acid to high specific activity in vitro by nick translation with DNA-polymerase I. Journal of Molecular Biology 113:237-251.

Riley T V, Mee B J 1981 Simple method of detecting Bacteroides spp. bacteriocin production. Journal of Clinical Microbiology 13:594-595.

Rotimi V O, Duerden B I 1982 Curing antibiotic resistance in Bacteroides species by aminoacridines and ethidium bromide. African Journal of Medicine and Medical Sciences 10:91-96.

Rotimi V O, Duerden B I, Hafiz S 1981 Transferable plasmid-mediated antibiotic resistance in Bacteroides. Journal of Medical Microbiology 14:359-370.

Schaffer H E, Sederoff R R 1981 Improved estimation of DNA fragment lengths from agarose gels. Analytical Biochemistry 115:113-122.

Sharp P A, Cohen S N, Davidson N 1973 Electron microscope heteroduplex studies of sequence relations among plasmids of Escherichia coli. II Structure of drug resistance (R) factors and F factors. Journal of Molecular Biology 75:235-255.

Stiffler P W, Keller R. Traub N 1974 Isolation and characterization of several cryptic plasmids from clinical isolates of Bacteroides fragilis. Journal of Infectious Diseases 130:544-548.

Tally F P, Shimell M J, Carson G R, Malamy M H 1981 Chromosomal and plasmid-mediated transfer of clindamycin resistance in Bacteroides fragilis. In: Levy S B, Clowes R C Koenig E L (eds) Molecular biology, pathogenicity and ecology of bacterial plasmids. Plenum Press, New York, pp 51-59.

Tally F P, Snydman D R, Gorbach S L, Malamy M H 1979 Plasmid-mediated, transferable resistance to clindamycin and erythromycin in Bacteroides fragilis. Journal of Infectious Diseases 139:83-88.

Tally F P, Snydman D R, Shimell M J, Malamy M H 1982 Characterization of pBFTM10, a clindamycin-erythromycin resistance transfer factor from Bacteroides fragilis. Journal of Bacteriology 151:686-691.

Varel V H, Bryant M P 1974 Nutritional features of Bacteroides fragilis subsp. fragilis. Applied Microbiology 18:251-257. 
Wallace B L, Bradley J E, Rogolsky M 1981 Plasmid analyses in clinical isolates of Bacteroides fragilis and other Bacteroides species. Journal of Clinical Microbiology 14:383-388.

Welch R A, Jones K R, Macrina F L 1979 Transferable lincosamide-macrolide resistance in Bacteroides. Plasmid 2:261-268.

Werner H 1981 Anaerobier-Infektionen: Pathogenese, Klinik, Therapie. Thieme-Verlag, Stuttgart.

Völlner E J, von Eichel-Streiber C, Schwindling F P 1983 Isolation and purification of plasmids from Bacteroides fragilis using rubidium trichloroacetate density gradient centrifugation. Molecular and General Genetics 189:169-171. 